\title{
Determining the Relationship between Bangkokian's Willingness to Receive COVID-19 Vaccination and their Knowledge, Attitude, and Practice (KAP) towards the Contagion
}

\author{
Pendhamma Sindhusen ${ }^{1}$, Apichaya Sinchaipanich ${ }^{2}$ \\ ${ }^{1,2}$ Patumwan Demonstration School
}

\begin{abstract}
In the age of COVID-19 where a lethal contagion is ubiquitous across the globe, vaccination is of supreme significance. Vaccines provide immunity to individuals, rendering them less susceptible to SARS-CoV-2 infection or their symptoms less severe should they ultimately become infected. Vaccinating an adequate proportion of the population can majorly contribute to the achievement of herd immunity, consequently depressing the spread of the Coronavirus and ushering humanity towards eventual subjugation of the ongoing pandemic. Unfortunately, there are obstacles preventing such a roseate prospect from realization, one of which is vaccine hesitancy. Interestingly, past research in various regions around the world has associated this factor, partially, with the public's knowledge and attitude concerning COVID-19, which could be measured by the Knowledge, Attitude and Practice (KAP) towards COVID-19 scale. Such an association plausibly intimates that a public campaign shedding light on accurate information about the contagion might be of help in augmenting people's willingness to receive vaccination against the SARS-CoV-2 virus. Because circumstances inevitably varied from place to place, population to population, this study was undertaken to explore whether any similar association existed in Bangkok, Thailand, where the pandemic has been growing progressively worse, with the initial hypothesis that it did. However, results revealed that while there was indeed a statistically significant correlation between Bangkokians' willingness to receive COVID-19 vaccines and their KAP towards the contagion, the correlation was weak $(r=0.30)$. This evinces the need for a more thorough and farther-reaching study and, until such a study has been meaningfully concluded, the appropriacy of apposite agencies concentrating elsewhere in their efforts to vanquish vaccine hesitancy and accomplish herd immunity against COVID-19.
\end{abstract}

KEYWORDS: Attitude and Practice (KAP) towards COVID-19; Bangkok population, Knowledge, Vaccine hesitancy; Willingness to receive vaccination; Herd immunity

\section{INTRODUCTION}

In most scenarios of disease outbreaks, vaccination is of significant gravity. By providing immunization for the population, vaccines can help to vanquish disease transmissions and attenuate adverse pathophysiological consequences engendered by infection (Plotkin, 1993). Moreover, because they provide immunization for the population, their extensive application could result in the population acquiring herd immunity, which contributes to the goal of conjugating the disease for which they are designed (Kim et al., 2011). Although other unique variables (such as the relatively rapid mutation of SARS-CoV-2 that has given rise to multiple variants that challenge the efficacy of currently available vaccines) are in play, the conceptualization of this proves to be the case for the ongoing Coronavirus pandemic that has extracted a hefty toll from humanity. Vaccines for COVID-19 have been proven to be effectual, albeit not to an immaculate extent, in preventing infection in healthy individuals and reducing severity of the disease in afflicted ones, which could pave the way for humanity toward herd immunity and relegating this grim pandemic to history (Katella, 2021). Unfortunately, despite their increasing availability for administration, there is an impediment that prevents such a gratifying goal from being fully achieved: vaccine hesitancy. The reluctance of some individuals to receive vaccination against the omnipresent contagion exists throughout the world (Machingaidze \& Wiysonge, 2021; Razai et al., 2021). Amplified by the PR crusades to raise skepticisms about COVID-19 vaccines, this reluctance indubitably represents a quandary for the prospect of putting the Coronavirus in humankind's rearview mirror and potentially results in unabated casualties from the virus (D' Souza \& Dowdy, 2021). An emphasis, therefore, should be placed on diminishing it and thereby ratcheting up the population's willingness to be vaccinated. Now, such an endeavor would necessitate a potently strategized campaign to change people's attitude towards vaccines, a step that 


\section{International Journal of Current Science Research and Review}

ISSN: 2581-8341

Volume 04 Issue 08 August 2021

DOI: 10.47191/ijcsrr/V4-i8-21, Impact Factor: 5.825

IJCSRR@ 2021

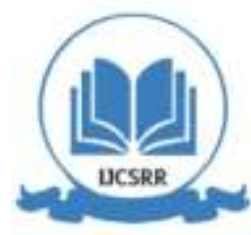

Www.ijcsrr.org

requires us to understand the factors influencing them. One of those factors is possibly knowledge and attitude towards COVID-19, which could be collectively quantified by the Knowledge, Attitude, and Practice towards COVID-19 (KAP) scale adapted from Lee et al. (2021). Multiple studies such as those of Wake (2021), Ciardi et al. (2021), and Huynh et al. (2021), suggest that the public's sentiment about vaccination against SARS-CoV-2 is partially dependent upon knowledge about the virus and the disease it causes and how serious a threat individuals perceive them to be. Accordingly, it is intriguing whether a media campaign better informing the public of COVID-19 could be of assistance in addition to one keeping the public abreast of the benefits of vaccines, which has been popular of late. Using the population of Bangkok metropolis - an area now heavily affected by SARS-CoV-2 and therefore in need of a substantial proportion of vaccinated individuals within the population — as a study group, this research was, therefore, conducted to shed light on this matter and provide a basis for interested authorities in devising public policy aimed at elevating vaccination rate with the utmost purpose that, more or less, it will contribute to humanity's eventual triumph over the Coronavirus contagion.

\section{METHODOLOGY}

In the conduction of this research and the study of the relationship between Bangkokians' willingness to receive COVID-19 vaccination and their knowledge, attitude, and practice towards COVID-19 (KAP), an online Google Forms questionnaire was devised and disseminated to a sample group of 407 individuals across age groups residing in the Bangkok Metropolis, a size that is sufficient for the city's population according to Joskow \& Yamane (1965). The questionnaire consisted of 27 questions with the first 3 questions inquiring about the respondents' age, education level, and history of prior vaccinations, the next 3 adapted from the work of Gan et al. (2021)'s and aimed at gauging their willingness to receive vaccination against the contagion, and the remaining ones adopted and aptly modified from Lee et al. (2021)'s Knowledge, Attitude, and Practice towards COVID-19 scale designed to measure the respondents' KAP. Each available response to any question in the 2 later portions of the survey was associated with an individual score that was eventually combined with their counterparts from the other questions and averaged to yield a holistic view of each respondent's standpoint, which was necessary for data interpretation. Before receiving its very first response, the questionnaire was submitted to experts for appraisal of its Item-Objective Congruence (IOC) value, an assessment criterion of reliability developed by Rovinelli \& Hambleton (1997). Conventionally, an IOC value threshold for questionnaire acceptability is 0.5 , which this questionnaire passed. It subsequently underwent a pilot test and returned with a Cronbrach's alpha value of 0.825 , which was sufficient for usability according to Cortina (1993). Afterwards, it was released for data collection, and once the data was adequately obtained, a statistical analysis was conducted on the responses received to determine the Pearson re coefficient between the sample group's willingness to be vaccinated against SARS-CoV-2 and its KAP, using the Statistical Product and Service Solutions (SPSS) software.

\section{RESULTS}

Table I: General demography of the respondents

\begin{tabular}{|l|l|l|}
\hline Personal information & Number of participants & Percentage \\
\hline 1) Gender & & \\
Female & 246 & 60.44 \\
Male & 154 & 37.84 \\
LGBTQ+ & 7 & 1.72 \\
\hline Total & 407 & 100 \\
\hline 2) Age & & \multicolumn{2}{|c|}{30.7130 .47} \\
$18-29$ & 125 & 38.82 \\
$30-49$ & 124 & 100 \\
50 or above & 158 & \\
\hline Total & 407 & \\
\hline
\end{tabular}




\section{International Journal of Current Science Research and Review}

ISSN: 2581-8341

Volume 04 Issue 08 August 2021

DOI: 10.47191/ijesrr/V4-i8-21, Impact Factor: 5.825

IJCSRR@ 2021

Www.ijcsrr.org

\begin{tabular}{|c|c|c|}
\hline \multicolumn{3}{|l|}{ 3) Highest Education Level } \\
\hline High school or below & 44 & 10.8151 .11 \\
\hline University (Bachelor's) & 208 & 38.08 \\
\hline Master's Degree or above & 155 & \\
\hline Total & 407 & 100 \\
\hline $\begin{array}{l}\text { 4) History of Influenza } \\
\text { Vaccination }\end{array}$ & & \\
\hline vaccine(s) & 268 & 65.85 \\
\hline $\begin{array}{l}\text { No history of vaccination against } \\
\text { influenza }\end{array}$ & 139 & 34.15 \\
\hline Total & 407 & 100 \\
\hline
\end{tabular}

The majority $(60.44 \%)$ of the respondents $(n=407)$ were female. In comparison, only $37.84 \%$ and $1.72 \%$ of them identified themselves as male and members of the LGBTQ+ community, respectively. $51.11 \%$ also reported their highest education level as a bachelor's degree, whereas $10.81 \%$ did as a high school diploma or below and $38.08 \%$ did as a master's degree or above. Despite the rather disproportionate division of the sample group in these 2 demographic facets, the respondents were more equally distributed across the age range although those identifying themselves as 50 years old or older constitute a slight plurality of $38.82 \%$. Interestingly, only $65.85 \%$ of the respondents claimed to have received at least 1 influenza vaccine while the remainder declared no flu vaccination history whatsoever.

Table II: Statistics of answers regarding willingness to receive COVID-19 vaccination (from the 3 questions adapted from Gan et al. (2021)'s questionnaire)

\begin{tabular}{|l|l|}
\hline Questions & Answers \\
\hline Do you trust the effectiveness of the COVID-19 vaccines? & Yes (79.8\%) No (20.2\%) \\
\hline Have you paid attention to the latest news of the vaccines? & Yes (88.9\%) No (11.1\%) \\
\hline Are you willing to receive vaccination against COVID-19? & Yes (87.2\%) No (12.8\%) \\
\hline
\end{tabular}

According to the data collected, the vast majority of the sample group $(n=407)$ asserted that they trusted the effectiveness of the vaccines against COVID-19 (79.85\%), had paid attention to the latest tidings about the vaccines (88.94\%) and were willing to be vaccinated against SARSCoV-2 (87.22\%). The empirical conjecture arising from the sight of these prodigious proportions that the sample group is highly eager to be vaccinated has been confirmed by statistical analysis that assigned scores to each yes and no answer and holistically evaluate each participant's responses although the data from such analysis was slightly underwhelming for the initial conjecture.

Table III: Statistics of the responses to the Knowledge, Attitude and Practice (KAP) portion of the questionnaire

\begin{tabular}{|c|c|}
\hline Questions & Answers \\
\hline \multicolumn{2}{|l|}{ Knowledge Qu estions } \\
\hline $\begin{array}{l}\text { Which of the following liquids is recommended for } \\
\text { disinfecting surfaces that have come in contact with Covid- } \\
19 \text { patients? }\end{array}$ & $\begin{array}{l}\text { Warm water }(1.6 \%) \\
25 \% \text { alcohol }(2.6 \%) \\
70 \% \text { alcohol }(27.3 \%) \\
95 \% \text { alcohol }(68.5 \%)\end{array}$ \\
\hline
\end{tabular}




\section{International Journal of Current Science Research and Review}

ISSN: 2581-8341

Volume 04 Issue 08 August 2021

DOI: 10.47191/ijesrr/V4-i8-21, Impact Factor: 5.825

IJCSRR@ 2021

Www.ijcsrr.org

\begin{tabular}{|c|c|}
\hline $\begin{array}{l}\text { The probability of contracting SARS-CoV-2 infection is } \\
\text { lower in which case? }\end{array}$ & $\begin{array}{l}\text { Talking to an infected person with no social } \\
\text { distancing }(4.5 \%) \\
\text { Sleeping with an infected person }(1.9 \%) \text { Online } \\
\text { video chat }(93.6 \%)\end{array}$ \\
\hline $\begin{array}{l}\text { Do you think Covid-19 is a severe disease that may cause } \\
\text { severe complications? }\end{array}$ & $\begin{array}{l}\text { Yes }(92.8 \%) \\
\text { No }(3.6 \%) \\
\text { I don't know }(3.6 \%)\end{array}$ \\
\hline \multicolumn{2}{|l|}{ Attitude Que stions } \\
\hline $\begin{array}{l}\text { Do you believe the Novel Coronavirus is undoubtedly } \\
\text { human-made to implement particular agendas? }\end{array}$ & $\begin{array}{l}\text { Yes }(13.3 \%) \\
\text { No }(20.5 \%) \\
\text { Maybe }(66.2 \%)\end{array}$ \\
\hline $\begin{array}{l}\text { Do you think that the local government policies would help } \\
\text { reduce the spread of the SARSCoV-2 virus? }\end{array}$ & Yes $(38.6 \%)$ No $(61.4 \%)$ \\
\hline $\begin{array}{l}\text { Do you think you are not at risk of contracting the COVID- } \\
19 \text { because your immunity is strong, and you do not need } \\
\text { to follow any precautionary measures? }\end{array}$ & Yes $(6.2 \%)$ No $(93.8 \%)$ \\
\hline $\begin{array}{l}\text { Do you believe maintaining a social distance from COVID- } \\
19 \text { suspected and confirmed cases would negatively impact } \\
\text { their psychology? }\end{array}$ & Yes $(46.8 \%)$ No $(53.2 \%)$ \\
\hline $\begin{array}{l}\text { Do you believe that the traditional remedies (i.e. herbs) } \\
\text { may protect from infectious diseases such as COVID-19? }\end{array}$ & Yes $(59.1 \%)$ No $(40.9 \%)$ \\
\hline $\begin{array}{l}\text { Should family members take care of their Covid-19 } \\
\text { patients to reduce the risks of transmitting the infection to } \\
\text { a single person? }\end{array}$ & Yes $(66.6 \%)$ No $(33.4 \%)$ \\
\hline $\begin{array}{l}\text { To which extent you agree that physical distancing can } \\
\text { protect you and your family from contacting Covid-19 } \\
\text { disease? }\end{array}$ & $\begin{array}{l}\text { Strongly agree }(61 \%) \\
\text { Agree }(29.5 \%) \\
\text { Neutral }(8.4 \%) \\
\text { Disagree }(1.1 \%) \\
\text { Strongly disagree }(0 \%)\end{array}$ \\
\hline $\begin{array}{l}\text { Do you agree that following precautionary measures on a } \\
\text { personal-level would help the community fight against the } \\
\text { COVID-19 pandemic? }\end{array}$ & Yes $(96.4 \%)$ No $(3.6 \%)$ \\
\hline \multicolumn{2}{|l|}{ COVID-19-related Pra ctice Questions } \\
\hline $\begin{array}{l}\text { In case you have had contact with the COVID19 case in the } \\
\text { last } 2 \text { weeks, and you then have felt feverish or shortness of } \\
\text { breath, which of the following steps should you do? }\end{array}$ & $\begin{array}{l}\text { Inform pertinent government agencies } \\
(13.3 \%) \\
\text { Inform family and friends }(20.5 \%) \text { Isolate yourself } \\
(66.2 \%)\end{array}$ \\
\hline $\begin{array}{l}\text { What should you do if you have been exposed to the } \\
\text { COVID-19, and you only informed later on? }\end{array}$ & $\begin{array}{l}\text { Isolate yourself and your family }(96.1 \%) \\
\text { Put on a face mask }(3.2 \%) \\
\text { Leave home only in urgent situations }(0.7)\end{array}$ \\
\hline
\end{tabular}




\section{International Journal of Current Science Research and Review}

ISSN: 2581-8341

Volume 04 Issue 08 August 2021

DOI: 10.47191/ijesrr/V4-i8-21, Impact Factor: 5.825

IJCSRR@ 2021

Www.ijesrr.org

\begin{tabular}{|c|c|}
\hline $\begin{array}{l}\text { Which of the following steps should you follow to take care } \\
\text { of a family member who has been }\end{array}$ & $\begin{array}{l}\text { Keep them in an isolated room with all windows } \\
\text { closed to prevent the transmission of infection } \\
(51.9 \%)\end{array}$ \\
\hline in contact with a case infected with SARS-CoV2? & $\begin{array}{l}\text { Cleaning their personal items such as bedding and } \\
\text { clothes on a daily basis } \\
(13.6 \%) \\
\text { Allowing friends and relatives to visit them but } \\
\text { only individually, not in group } \\
(0.7 \%) \\
\text { Washing hands with soap and water and using } \\
\text { medical gloves while caring for } \\
\text { them }(33.8 \%)\end{array}$ \\
\hline $\begin{array}{l}\text { Which of the following measures should be undertaken to } \\
\text { deal with the corpse of a patient who died from COVID- } \\
\text { 19? }\end{array}$ & $\begin{array}{l}\text { Washing and depositing the deceased is considered } \\
\text { safe and must be allowed to respect the relatives } \\
\text { and friends }(7.1 \%) \\
\text { Funerals should not be allowed at all } \\
(23.7 \%) \\
\text { Funerals are only permitted under strict } \\
\text { precautionary policies }(69.2 \%)\end{array}$ \\
\hline What is the best method to clean your hands? & $\begin{array}{l}\text { Wash hands only with water }(1 \%) \\
\text { Wash hands with soap and water }(55.5 \%) \\
\text { Wash hands with a disinfectant handwash }(43.5 \%)\end{array}$ \\
\hline How do you greet your colleagues at work or at school? & $\begin{array}{l}\text { By shaking hands }(1 \%) \\
\text { By hugging each other }(1.6 \%) \\
\text { Only verbal greeting }(97.4 \%)\end{array}$ \\
\hline When are you going to cough or sneeze? & $\begin{array}{l}\text { I usually sneeze or cough into my hand palms } \\
(19.8 \%) \\
\text { I usually sneeze and cough into my elbow (58.1\%) } \\
\text { I prevent myself from coughing/sneezing } \\
(20.1 \%) \\
\text { I cough/sneeze freely and without covers, because } \\
\text { viruses do not live outside the body ( } 2 \%)\end{array}$ \\
\hline $\begin{array}{l}\text { Do you practice social distancing, especially when dealing } \\
\text { with people who express symptoms of a cold or a fever? }\end{array}$ & Yes $(97.7 \%)$ No $(2.3 \%)$ \\
\hline Do you routinely wear a face mask when you go out? & Yes $(100 \%)$ No $(0 \%)$ \\
\hline $\begin{array}{l}\text { Do you perform the protective measures, including social } \\
\text { distancing, to protect yourself from getting the COVID- } \\
\text { 19? }\end{array}$ & Yes $(99.7 \%)$ No $(0.3 \%)$ \\
\hline
\end{tabular}

Illustrated by the data in this table, only several certain questions demonstrate unity in how the survey participants responded to them. However, these questions are overwhelmed by many others where there is a mélange of different responses. This attests to the fact that overall, the sample group possessed a diverse range of knowledge, attitude and practice towards COVID-19, which presents a case different from its collective willingness to receive COVID-19 vaccination. 


\section{International Journal of Current Science Research and Review}

ISSN: 2581-8341

Volume 04 Issue 08 August 2021

DOI: 10.47191/ijesrr/V4-i8-21, Impact Factor: 5.825

IJCSRR@ 2021

Www.ijcsrr.org

Table IV: Statistics of average scores for the sample group's KAP and its willingness to receive COVID-19 vaccination (rounded up to 2 decimal places)

\begin{tabular}{|l|l|l|l|}
\hline & \multicolumn{1}{|c|}{ Mean (Total Range: 0-2) } & Standard Deviation & N \\
\hline $\begin{array}{l}\text { Willingness to receive } \\
\text { COVID-19 vaccination }\end{array}$ & 1.70 & 0.49 & 407 \\
\hline KAP & 1.48 & 0.16 & 407 \\
\hline
\end{tabular}

The calculations subsequent to data harvesting revealed the average willingness to receive COVID-19 vaccination to be 1.70 on a scale of 2 with the standard deviation value of 0.49 and the average KAP of 1.48 out of 2 with a smaller deviation of 0.16 . This confirms that the sample group has a relatively high desire to get vaccinated against SARS-CoV-2 and a level of appropriate knowledge, attitude and practice relevant to COVID-19 that, although not exceedingly low, fails to parallel it.

Table V: The Pearson Correlation value between the respondents' willingness to receive COVID-19 vaccination and their KAP (rounded up to 2 decimal places)

\begin{tabular}{|l|l|l|l|}
\hline \multicolumn{2}{|l|}{} & $\begin{array}{l}\text { Willingness to receive } \\
\text { COVID-19 vaccination }\end{array}$ & KAP \\
\hline $\begin{array}{l}\text { Willingness to receive } \\
\text { COVID-19 vaccination }\end{array}$ & Pearson Correlation & 1 & 0.30 \\
\cline { 2 - 4 } & N & 407 & 407 \\
\hline \multirow{2}{*}{ KAP } & Pearson Correlation & 0.30 & 1 \\
\cline { 2 - 4 } & N & 407 & 407 \\
\hline
\end{tabular}

According to the correlation test's result, a Pearson correlation efficient of 0.30 was calculated.

This value indicates a weak correlation between the willingness be vaccinated against COVID19 and KAP that bears statistical significance. Although it does not completely contradict the initial hypothesis of this research, it is much underwhelming.

\section{DISCUSSION}

The results of this research reveal only a weak positive correlation between the willingness to receive vaccination against COVID19 and knowledge, attitude and practice towards the contagion amongst the population of Bangkok. They demonstrate an arrant aberration from the conventional notion and findings brought forward by the aforementioned works of Wake (2021), Ciardi et al. (2021), and Huynh et al. (2021), all of which indicated a stalwart relationship between COVID-19 vaccine hesitancy and the public's awareness about SARS-CoV-2, at least to an extent. Plausibly, the unanticipated and rather nonplussing nature of this aberration lies in the present landscape of the COVID-19 pandemic and the political firestorm befalling Thailand and dominating its climate for the foreseeable future. According to statistics from the country's own Department of Disease Control and the World Health Organization, the numbers of confirmed cases and fatalities per day have now reached an altitude foreign to what was observed only a month ago. This represents a serious aggravation of the situation, which likely translates into an elevation in the perceived risk of contracting the disease, a factor that İkiışı et al. (2021) found to be influential upon the public's sentiment towards COVID-19 vaccines. Such an aggravation also likely translates into economic concerns, which could be substantiated by the progressing dilapidation of the Thai economy (World Bank, 2021; Yuvejwattana \& ThanthongKnight, 2021; Polkuamdee, 2021), a factor that has a propensity to ratchet up the public's vaccine acceptance (Bendau et al., 2021). Additionally, the grim trajectory of Thailand's Coronavirus situation in the past several months despite the implementation of lockdowns has severely antagonized anti-government protestors, who were initially already antipathetic towards the incumbent government administration on political grounds, leading to the incorporation of how essential COVID-19 vaccines are to resolving the present predicament into their rhetoric

(Thanthong-Knight, 2021). Through the butterfly effect and peer pressure, among other things, (Özdemir et al., 2013; Hughes, 2018), all these aforementioned factors could drive up the populace's willingness to receive vaccination without affecting its overall 


\section{International Journal of Current Science Research and Review}

ISSN: 2581-8341

Volume 04 Issue 08 August 2021

DOI: 10.47191/ijcsrr/V4-i8-21, Impact Factor: 5.825

IJCSRR@ 2021

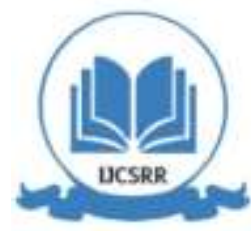

WWW.ijcsrr.org

KAP, thereby wielding influence over the variable to an extent that completely dwarfs what possible effects KAP might have. Should such a postulation be true, it would yield a clarion testimony regarding the anomalous quality of this research's findings and affirm that it might be more advantageous for relevant organizations to concentrate on other factors to diminish vaccine hesitancy. Nevertheless, a more in-depth and extensive study of a larger scale, perhaps a meta-analysis, which simultaneously takes into account other potentially influential factors as well is to be undertaken before one reaches any conclusion that will affect the configuration of public relations campaigns promoting vaccination in any way, shape, or form.

\section{CONCLUSION}

This study was initiated to study whether people's willingness to receive vaccination against COVID-19 is somehow influenced by or correlated with their existing knowledge and attitude towards the contagion. It specifically targeted the population of Bangkok, where the circumstances are contemporarily slightly divergent from those of other areas in the world, hoping to provide a basis that could be helpful to policymakers in their endeavor to increase the rate of vaccine acceptance and administration amidst a raging pandemic. The initial hypothesis, influenced in part by inferences from previous research bearing partial resemblance, was that the 2 factors were correlated. This hypothesis was slightly supported by the findings later brought forward, which revealed a weak relationship between them and were faintly inconsistent with the other studies in other populations that had indicated a stronger relationship. The ambiguity of such findings warrants an even more extensive and meticulous studies to investigate whether promoting the Bangkok populace's knowledge and apt attitude regarding COVID-19 could render them more eager to receive the COVID-19 vaccines. Until a definitive answer can be presented, it would be best that public information campaigns to reduce vaccine hesitancy shift their focus onto other items that possibly bear more clout than knowledge and attitude towards the contagion.

\section{REFERENCES}

1. Plotkin, S. A. (1993). Vaccination in the 21st Century. The Journal of Infectious Diseases, 168(1), 29-37. https://doi.org/10.1093/infdis/168.1.29

2. Kim, T. H., Johnstone, J., \& Loeb, M. (2011). Vaccine herd effect. Scandinavian Journal of Infectious Diseases, 43(9), 683-689. https://doi.org/10.3109/00365548.2011.582247

3. Katella, K. (2021, August 13). Comparing the COVID-19 Vaccines: How Are They Different? Yale Medicine. https://www.yalemedicine.org/news/covid-19-vaccine-comparison

4. Machingaidze, S., \& Wiysonge, C. S. (2021). Understanding COVID-19 vaccine hesitancy. Nature Medicine, 27(8), 1338-1339. https://doi.org/10.1038/s41591-021-01459-7

5. Razai, M. S., Chaudhry, U. A. R., Doerholt, K., Bauld, L., \& Majeed, A. (2021). Covid-19 vaccination hesitancy. BMJ, n1138. https://doi.org/10.1136/bmj.n1138

6. D'Souza, G., \& Dowdy, D. (2021, April 6). What is Herd Immunity and How Can We Achieve It With COVID-19? Johns Hopkins Bloomberg School of Public Health. https://publichealth.jhu.edu/2021/what-is-herd-immunity-and-how-can-we-achieve-it-withcovid-19

7. Lee, M., Kang, B. A., \& You, M. (2021). Knowledge, attitudes, and practices (KAP) toward COVID-19: a cross-sectional study in South Korea. BMC Public Health, 21(1). https://doi.org/10.1186/s12889-021-10285-y

8. Wake, A. D. (2021). The Willingness to Receive COVID-19 Vaccine and Its Associated Factors: "Vaccination Refusal Could Prolong the War of This Pandemic" - A Systematic Review. Risk Management and Healthcare Policy, Volume 14, 2609-2623. https://doi.org/10.2147/rmhp.s311074

9. Ciardi, F., Menon, V., Jensen, J. L., Shariff, M. A., Pillai, A., Venugopal, U., Kasubhai, M., Dimitrov, V., Kanna, B., \& Poole, B. D. (2021). Knowledge, Attitudes and Perceptions of COVID-19 Vaccination among Healthcare Workers of an Inner-City Hospital in New York. Vaccines, 9(5), 516. https://doi.org/10.3390/vaccines9050516

10. Huynh, G., Nguyen, T. V., Nguyen, D. D., Lam, Q. M., Pham, T. N., \& Nguyen, H. T. N. (2021). Knowledge About COVID-19, Beliefs and Vaccination Acceptance Against COVID19 Among High-Risk People in Ho Chi Minh City, Vietnam. Infection and Drug Resistance, Volume 14, 1773-1780. https://doi.org/10.2147/idr.s308446 


\section{International Journal of Current Science Research and Review}

ISSN: 2581-8341

Volume 04 Issue 08 August 2021

DOI: 10.47191/ijesrr/V4-i8-21, Impact Factor: 5.825

IJCSRR@ 2021

www.ijcsrr.org

11. Joskow, J., \& Yamane, T. (1965). Statistics, an Introductory Analysis. Journal of the American Statistical Association, 60(310), 678. https://doi.org/10.2307/2282703

12. Gan, L., Chen, Y., Hu, P., Wu, D., Zhu, Y., Tan, J., Li, Y., \& Zhang, D. (2021). Willingness to Receive SARS-CoV-2 Vaccination and Associated Factors among Chinese Adults: A Cross Sectional Survey. International Journal of Environmental Research and Public Health, 18(4), 1993. https://doi.org/10.3390/ijerph18041993

13. Rovinelli, R., \& Hambleton, R. (1976). On the Use of Content Specialists in the Assessment of Criterion-Referenced Test Item Validity.

14. Cortina, J. M. (1993). What is coefficient alpha? An examination of theory and applications. Journal of Applied Psychology, 78(1), 98-104. https://doi.org/10.1037/0021-9010.78.1.98

15. Thai Department of Disease Control. (2021, August 22). Corona Virus Disease (COVID-19): Thailand Situation. Corona Virus Disease (COVID-19). https://ddc.moph.go.th/viralpneumonia/eng/index.php.

16. World Health Organization. (n.d.). Thailand Situation Reports. World Health Organization Official Website. Retrieved August 22, 2021, from https://www.who.int/thailand/emergencies/novel-coronavirus-2019/situation-reports

17. İKiışı, H., Akif Sezerol, M., Taşçı, Y., \& Maral, I. (2021). COVID-19 vaccine hesitancy: A community-based research in Turkey. International Journal of Clinical Practice, 75(8). https://doi.org/10.1111/ijcp.14336

18. World Bank. (2021, July 15). COVID-19 Crisis Lowers Thailand's Growth, Continued Support for the Poor Needed. https://www.worldbank.org/en/news/press-release/2021/07/15/covid-19-crisis-lowers-thailand-s-growth-continuedsupport-for-the-poorneeded

19. Yuvejwattana , S., \& Thanthong-Knight, R. (2021, July 12). Thailand's Lockdown-Like Virus Curbs Dent Economic Recovery. Bloomberg.com. https://www.bloomberg.com/news/articles/2021-07-11/thailand-s-lockdown-like-viruscurbsdent-economic-recovery-bets.

20. Polkuamdee, N. (2021, July 28). Prolonged Lockdowns to Cause GDP Drop. https://www.bangkokpost.com. https://www.bangkokpost.com/business/2155783/prolongedlockdowns-to-cause-gdp-drop.

21. Bendau, A., Plag, J., Petzold, M. B., \& Ströhle, A. (2021). COVID-19 vaccine hesitancy and related fears and anxiety. International Immunopharmacology, 97, 107724. https://doi.org/10.1016/j.intimp.2021.107724

22. Thanthong-Knight, R. (2021, July 14). Bloomberg.com. https://www.bloomberg.com/news/articles/2021-07-14/thaiprotesters-adopt-vaccinedemand-in-push-to-widen-support.

23. Özdemir, O., Özdemir, P., \& Y1lmaz, E. (2014). The Butterfly Effect in Psychiatry: A case example. Journal of Mood Disorders, 4, 34. https://doi.org/10.5455/jmood.20131205063836

24. Hughes, Jordan, "The Art of Peer Pressure: Social Desires as Incentives to Join Students Protests in Jordan" (2018). Independent Study Project (ISP) Collection. 2826. https://digitalcollections.sit.edu/isp_collection/2826

Cite this Article: Pendhamma Sindhusen, Apichaya Sinchaipanich (2021). Determining the Relationship between Bangkokian's Willingness to Receive COVID-19 Vaccination and their Knowledge, Attitude, and Practice (KAP) towards the Contagion. International Journal of Current Science Research and Review, 4(8), 1035-1042 